\title{
Panosialins, Inhibitors of Enoyl-ACP Reductase from Streptomyces sp. AN1761
}

\author{
Kwon, Yun $\mathrm{Ju}^{1}$, Mi-Jin Sohn ${ }^{1}$, Taegwon $\mathrm{Oh}^{2}$, Sang-Nae Cho ${ }^{2}$, Chang-Jin Kim ${ }^{1}$, and Won-Gon Kim ${ }^{1 *}$ \\ ${ }^{1}$ Environmental Biotechnology Research Center, Korea Research Institute of Bioscience and Biotechnology, Daejeon 305-806, \\ Korea \\ ${ }^{2}$ Department of Microbiology and the Brain Korea 21 Project for the Medical Sciences, Yonsei University College of Medicine, \\ Seoul 120-752, Korea
}

Received: September 13, 2012 / Revised: October 16, 2012 / Accepted: October 17, 2012

\begin{abstract}
In the continued search for inhibitors of enoyl-acyl carrier protein (ACP) reductase, we found that four acylbenzenediol sulfate metabolites from Streptomyces sp. AN1761 potently inhibited bacterial enoyl-ACP reductases of Staphylococcus aureus, Streptococcus pneumoniae, and Mycobacterium tuberculosis. Their structures were identified as panosialins A, B, wA, and wB by MS and NMR data. They showed stronger inhibition against $S$. aureus FabI and $S$. pneumoniae FabK with $\mathrm{IC}_{50}$ of $3-5 \mu \mathrm{M}$ than $M$. tuberculosis $\mathrm{InhA}$ with $\mathrm{IC}_{50}$ of 9-12 $\mu \mathrm{M}$. They also exhibited a stronger antibacterial spectrum on $S$. aureus and $S$. pneumoniae than $M$. tuberculosis. In addition, the higher inhibitory activity of panosialin $\mathrm{wB}$ than panosialin $B$ on fatty acid biosynthesis was consistent with that on bacterial growth, suggesting that they could exert their antibacterial activity by inhibiting fatty acid synthesis.
\end{abstract}

Key words: Panosialin, enoyl-ACP reductase, inhibitor, Staphylococcus aureus, antibacterial

Bacterial fatty acid synthesis (FAS II) is an attractive antibacterial target since FAS is organized differently in bacteria and mammals $[2,4]$. Bacterial enoyl-ACP reductase catalyzes the final and rate-limiting step in bacterial fatty acid synthesis $[8,11]$. There are three isoforms, FabI, FabK, and FabL, in enoyl-ACP reductase. FabI is distributed broadly throughout the majority of bacteria including $S$. aureus, whereas Streptococcus pneumoniae contains only FabK, Enterococcus faecalis and Pseudomonas aeruginosa contain both FabI and FabK, and Bacillus subtilis contains both FabI and FabL. InhA is a FabI homolog in $M$. tuberculosis. Bacterial enoyl-ACP reductase has been validated as an excellent target for antibacterial drug

* Corresponding author

Phone: +82 42860 4298; Fax: +82 42879 8103;

E-mail: wgkim@kribb.re.kr development since FabI and InhA have been identified as the antibacterial target of triclosan and isoniazid, respectively $[7,9]$. Triclosan is a broad-spectrum biocide used in a wide range of consumer goods, and isoniazid has been utilized for 50 years in the treatment of tuberculosis. Therefore, inhibitors of enoyl-ACP reductase could be interesting lead compounds for treatment of multidrug-resistant bacteria.

In our continued screening of inhibitors of enoyl-ACP reductase from microbial resources $[6,12]$, four acylbenzenediol sulfate metabolites were isolated from Streptomyces sp. AN1761. The isolated compounds were identified as panosialins A (1), B (2), wA (3), and wB (4), rare microbial metabolites, by spectral analysis (Fig. 1) [5]. Panosialins A and B have been reported as the inhibitors of viral sialidase [1] and panosialins $\mathrm{A}, \mathrm{B}, \mathrm{wA}$, and $\mathrm{wB}$ as inhibitors of glycosidases together with brief antibacterial activity [10]. Their antibacterial activity, however, has yet to be thoroughly examined. In this study, we report the isolation, inhibitory activity against bacterial enoyl-ACP reductases and intracellular fatty acid biosynthesis, and antibacterial activity of $\mathbf{1 - 4}$.

The strain AN1761 was isolated from a soil sample collected from a mountain located near Gongju-city, Chungcheongnam-do, Korea. This strain was identified as a Streptomyces species on the basis of its 16S rDNA sequence. Fermentation was conducted in a liquid culture medium containing soluble starch $1 \%$, glucose $2 \%$, soybean meal $2.5 \%$, beef extract $0.1 \%$, yeast extract $0.4 \%$, $\mathrm{NaCl} 0.2 \%, \mathrm{~K}_{2} \mathrm{HPO}_{4} 0.025 \%$, and $\mathrm{CaCO}_{3} 0.2 \%$ (adjusted to $\mathrm{pH} 7.2$ before sterilization). A piece of the AN1761 strain from a mature plate culture was inoculated into a $500 \mathrm{ml}$ Erlenmeyer flask containing $80 \mathrm{ml}$ of the above sterile seed liquid medium and cultured for 3 days on a rotary shaker $(150 \mathrm{rpm})$ at $28^{\circ} \mathrm{C}$. For the production of active compounds, $5 \mathrm{ml}$ of the seed culture was transferred into $500 \mathrm{ml}$ Erlenmeyer flasks (65 flasks) containing $100 \mathrm{ml}$ of the same medium, and then cultivated for 7 days at 

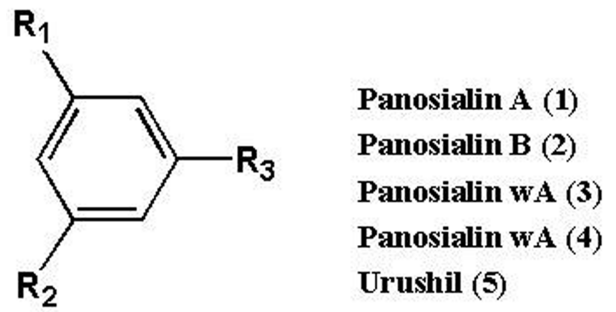

\begin{tabular}{cl}
\multicolumn{1}{c}{$\mathrm{R}_{1}$} & \multicolumn{1}{c}{$\mathrm{R}_{2}$} \\
$\mathrm{OSO}_{3} \mathrm{Na}$ & $\mathrm{OSO}_{3} \mathrm{Na}$ \\
$\mathrm{OSO}_{3} \mathrm{Na}$ & $\mathrm{OSO}_{3} \mathrm{Na}$ \\
$\mathrm{OSO}_{3} \mathrm{Na}$ & $\mathrm{OH}$ \\
$\mathrm{OSO}_{3} \mathrm{Na}$ & $\mathrm{OH}$ \\
$\mathrm{OH}$ & $\mathrm{OH}$
\end{tabular}

$\mathrm{R}_{3}$
$\left(\mathrm{CH}_{2}\right)_{12}-\mathrm{CH}\left(\mathrm{CH}_{3}\right)_{2}$
$\left(\mathrm{CH}_{2}\right)_{14}-\mathrm{CH}_{3}$
$\left(\mathrm{CH}_{2}\right)_{12}-\mathrm{CH}\left(\mathrm{CH}_{3}\right)_{2}$
$\left(\mathrm{CH}_{2}\right)_{14}-\mathrm{CH}_{3}$
$\left(\mathrm{CH}_{2}\right)_{14}-\mathrm{CH}_{3}$

Fig. 1. Structures of panosialins A (1), B (2), wA (3), and wB (4), and related compound.

$28^{\circ} \mathrm{C}$. The fermented whole medium $(2 \mathrm{~L})$ was extracted with $50 \%$ acetone and the extract was concentrated in vacuo to an aqueous solution, which was then extracted three times with an equal volume of EtOAc. The EtOAc extract was concentrated to dryness in vacuo. The crude extract was then subjected to $\mathrm{SiO}_{2}$ column chromatography followed by stepwise elution with $\mathrm{CHCl}_{3}-$ $\mathrm{MeOH}(10: 1,5: 1,3: 1,1: 1)$ to afford two active fractions. The first active fractions eluted with $\mathrm{CHCl}_{3}-\mathrm{MeOH}(5: 1)$ were pooled and concentrated in vacuo. The residue dissolved in $\mathrm{MeOH}$ was purified via preparative $\mathrm{SiO}_{2}$ thinlayer chromatography developed with $\mathrm{CHCl}_{3}-\mathrm{MeOH}$ (3:1) containing $0.1 \%$ TFA to yield an active band $(12.7 \mathrm{mg})$ at an $R_{f}$ of 0.35 . The active band was further purified by reversed-phase HPLC. The column was eluted with ACN$25 \mathrm{mM}$ sodium phosphate $(\mathrm{pH}$ 7.0) (65:35) at a flow rate of $7 \mathrm{ml} / \mathrm{min}$ to afford 3 and $\mathbf{4}$, with retention times of 14.8 and $16.2 \mathrm{~min}$, respectively. They were desalted by a MCI gel column to yield $2.6 \mathrm{mg}$ of 3 and $4.7 \mathrm{mg}$ of 4 . The second active fractions eluted with $\mathrm{CHCl}_{3}-\mathrm{MeOH}$ (3:1) were pooled and concentrated in vacuo. The residue dissolved in $\mathrm{MeOH}$ was again applied to a Sephadex LH20 column and then eluted with $\mathrm{MeOH}$. The active fractions residue dissolved in $\mathrm{MeOH}$ was purified via preparative $\mathrm{SiO}_{2}$ thin-layer chromatography developed with $\mathrm{CHCl}_{3}-\mathrm{MeOH}$ (2:1) containing $0.1 \%$ TFA to yield an active band $(16.5 \mathrm{mg})$ at an $\mathrm{R}_{\mathrm{f}}$ of 0.2 . The active band was further purified by reversed-phase HPLC chromatography eluted with ACN-50 mM sodium phosphate ( $\mathrm{pH}$ 7.0) (78:22) at a flow rate of $3.5 \mathrm{ml} / \mathrm{min}$ to afford $\mathbf{1}$ and $\mathbf{2}$, with retention times of 34.8 and $38.5 \mathrm{~min}$, respectively. They were also desalted by a MCI gel column to yield $2.5 \mathrm{mg}$ of $\mathbf{1}$ and $5.1 \mathrm{mg}$ of $\mathbf{2}$. The structures of $\mathbf{1 - 4}$ were determined as panosialins $\mathrm{A}, \mathrm{B}, \mathrm{wA}$, and $\mathrm{wB}$, respectively, by NMR and MS spectral data $[5,10]$. The ${ }^{1} \mathrm{H}-$ and ${ }^{13} \mathrm{C}$-NMR data of panosialins $\mathrm{A}$ and $\mathrm{B}$ were reported for the first time in this study. NMR spectra were recorded on a Bruker Biospin Avance 500 spectrometer (Korea Basic Science Institute). ESI-MS data were obtained with a Finnigan Navigator spectrometer.

Compound 1: $\mathrm{C}_{21} \mathrm{H}_{34} \mathrm{Na}_{2} \mathrm{O}_{8} \mathrm{~S}_{2}$, a white powder. ${ }^{1} \mathrm{H}-\mathrm{NMR}$ $\left(500 \mathrm{MHz}, \mathrm{CD}_{3} \mathrm{OD}\right): \delta 7.05(1 \mathrm{H}, \mathrm{dd}, J=2.0,2.0, \mathrm{H}-2)$, $6.99(2 \mathrm{H}, \mathrm{d}, J=2.0, \mathrm{H}-4$ and 6$), 2.58\left(2 \mathrm{H}, \mathrm{t}, J=7.5, \mathrm{H}_{2}-1^{\prime}\right)$, $1.61\left(2 \mathrm{H}, \mathrm{m}, \mathrm{H}_{2}-2^{\prime}\right), 1.51\left(1 \mathrm{H}, \mathrm{q}, J=7.0, \mathrm{H}_{2}-13^{\prime}\right), 1.28$ (18H, m, $\mathrm{H}_{2}-3^{\prime}$ to $\left.11^{\prime}\right), 1.17\left(2 \mathrm{H}, \mathrm{m}, \mathrm{H}_{2}-12^{\prime}\right), 0.87(6 \mathrm{H}, \mathrm{d}, J$ $=7.0, \mathrm{H}_{3}-14^{\prime}$ and $\left.15^{\prime}\right) ;{ }^{13} \mathrm{C}-\mathrm{NMR}\left(200 \mathrm{MHz}, \mathrm{CD}_{3} \mathrm{OD}\right): \delta$ 154.3 (C-1 and 3), 145.9 (C-5), 118.9 (C-4 and 6), 113.4 (C-2), 40.4 (C-12'), 37.0 (C-1'), 32.5 (C-2'), 30.6 - 31.2 (C$3^{\prime}$ to $\left.10^{\prime}\right), 29.3$ (C-13'), 28.7 (C-11'), 23.2 (C-14' and $\left.15^{\prime}\right)$; ESI-MS: $547.3[\mathrm{M}+\mathrm{Na}]^{+}, 501.3[\mathrm{M}-\mathrm{Na}]^{-}$.

Compound 2: $\mathrm{C}_{21} \mathrm{H}_{34} \mathrm{Na}_{2} \mathrm{O}_{8} \mathrm{~S}_{2}$, a white powder. ${ }^{1} \mathrm{H}-\mathrm{NMR}$ $\left(500 \mathrm{MHz}, \mathrm{CD}_{3} \mathrm{OD}\right) \delta 7.05(1 \mathrm{H}, \mathrm{dd}, J=2.0,2.0, \mathrm{H}-2), 6.99$ $(2 \mathrm{H}, \mathrm{d}, J=2.0, \mathrm{H}-4$ and 6$), 2.58\left(2 \mathrm{H}, \mathrm{t}, J=7.5, \mathrm{H}_{2}-1\right.$ '), 1.61 $\left(2 \mathrm{H}, \mathrm{m}, \mathrm{H}_{2}-2^{\prime}\right), 1.28\left(24 \mathrm{H}, \mathrm{m}, \mathrm{H}_{2}-3^{\prime}\right.$ to $\left.14^{\prime}\right), 0.89$ (3H, d, $J=$ 7.5, $\left.\mathrm{H}_{3}-15^{\prime}\right) ;{ }^{13} \mathrm{C}-\mathrm{NMR}\left(200 \mathrm{MHz}, \mathrm{CD}_{3} \mathrm{OD}\right) \delta: 154.3$ (C-1 and 3), 145.9 (C-5), 118.9 (C-4 and 6), 113.4 (C-2), 37.0 (C-1'), 33.2 (C-13'), 32.5 (C-2'), $30.6-30.9$ (C-3' to 12'), 23.9 (C-14'), 14.6 (C-15'); ESI-MS: $547.3[\mathrm{M}+\mathrm{Na}]^{+}, 501.3$ $[\mathrm{M}-\mathrm{Na}]$.

Compound 3: $\mathrm{C}_{21} \mathrm{H}_{35} \mathrm{NaO}_{5} \mathrm{~S}$, a white powder. ${ }^{1} \mathrm{H}-\mathrm{NMR}$ $\left(500 \mathrm{MHz}, \mathrm{CD}_{3} \mathrm{OD}\right): \delta 6.62(1 \mathrm{H}, \mathrm{dd}, J=2.1,2.0, \mathrm{H}-4)$, $6.60(1 \mathrm{H}, \mathrm{dd}, J=2.1,2.0, \mathrm{H}-2), 6.42(1 \mathrm{H}, \mathrm{dd}, J=2.1,2.0$, $\mathrm{H}-6), 2.50\left(2 \mathrm{H}, \mathrm{t}, J=7.5, \mathrm{H}_{2}-1^{\prime}\right), 1.58\left(2 \mathrm{H}, \mathrm{m}, \mathrm{H}_{2}-2^{\prime}\right), 1.52$ $\left(1 \mathrm{H}, \mathrm{q}, J=7.0, \mathrm{H}_{2}-13^{\prime}\right), 1.28\left(18 \mathrm{H}, \mathrm{m}, \mathrm{H}_{2}-3^{\prime}\right.$ to $\left.11^{\prime}\right), 1.16$ $\left(2 \mathrm{H}, \mathrm{m}, \mathrm{H}_{2}-12^{\prime}\right), 0.87\left(6 \mathrm{H}, \mathrm{d}, J=7.0, \mathrm{H}_{3}-14^{\prime}\right.$ and $\left.15^{\prime}\right) ;{ }^{13} \mathrm{C}-$ NMR (200 MHz, $\left.\mathrm{CD}_{3} \mathrm{OD}\right): \delta 159.1$ (C-1), 154.8 (C-3), 146.2 (C-5), 113.8 (C-4), 113.1 (C-6), 107.2 (C-2), 40.4 (C-12'), 37.1 (C-1'), 32.5 (C-2'), $30.5-31.2$ (C-3' to $\left.10^{\prime}\right)$, 29.3 (C-13'), 28.7 (C-11'), 23.2 (C-14' and 15'); ESI-MS : $445.4[\mathrm{M}+\mathrm{Na}]^{+}, 399.4[\mathrm{M}-\mathrm{Na}]^{-}$.

Compound 4: $\mathrm{C}_{21} \mathrm{H}_{35} \mathrm{NaO}_{5} \mathrm{~S}$, a white powder. ${ }^{1} \mathrm{H}-\mathrm{NMR}$ $\left(500 \mathrm{MHz}, \mathrm{CD}_{3} \mathrm{OD}\right): \delta 6.61(1 \mathrm{H}, \mathrm{dd}, J=2.1,2.0, \mathrm{H}-4)$, $6.59(1 \mathrm{H}, \mathrm{dd}, J=2.1,2.0, \mathrm{H}-2), 6.42(1 \mathrm{H}, \mathrm{dd}, J=2.1,2.0$, $\mathrm{H}-6), 2.50\left(2 \mathrm{H}, \mathrm{t}, J=7.5, \mathrm{H}_{2}-1^{\prime}\right), 1.58\left(2 \mathrm{H}, \mathrm{m}, \mathrm{H}_{2}-2^{\prime}\right), 1.28$ $\left(24 \mathrm{H}, \mathrm{m}, \mathrm{H}_{2}-3^{\prime}\right.$ to $\left.14^{\prime}\right), 0.88\left(3 \mathrm{H}, \mathrm{d}, J=7.5, \mathrm{H}_{3}-15^{\prime}\right) ;{ }^{13} \mathrm{C}-$ NMR (200 MHz, CD $\mathrm{OD}): \delta 159.0$ (C-1), 154.8 (C-3), 146.1 (C-5), 113.8 (C-4), 113.1 (C-6), 107.1 (C-2), 37.0 (C-1'), 33.2 (C-13'), 32.5 (C-2'), $30.5-30.9$ (C-3' to 12'), 23.9 (C-14'), 14.6 (C-15'); ESI-MS: 445.4 [M+Na $]^{+}, 399.4$ [M-Na].

Urushil was purchased from Alfa Aesar (Ward Hill, MA, USA). Triclosan was purchased from Sigma. $\left[1-{ }^{14} \mathrm{C}\right]$ Acetate $(57 \mu \mathrm{Ci} / \mathrm{mol})$ and $\mathrm{L}-\left[\mathrm{U}-{ }^{14} \mathrm{C}\right]$ leucine $(306 \mu \mathrm{Ci} / \mathrm{mol})$ were purchased from Amersham.

S. aureus FabI, S. pneumoniae FabK, and M. tuberculosis InhA enzymes were cloned, overexpressed, and purified as 
previously described $[6,13]$. Assays were conducted in half-area, 96-well microtiter plates. The compounds were evaluated in $100 \mu \mathrm{l}$ assay mixtures containing components specific to each enzyme (see below). The reduction of the trans-2-octenoyl $\mathrm{N}$-acetylcysteamine (t-o-NAC thioester) substrate analog was spectrophotometrically measured by following the utilization of NADH or NADPH at $340 \mathrm{~nm}$ at $30^{\circ} \mathrm{C}$ over the linear period of the assay. S. aureus FabI assays contained $50 \mathrm{mM}$ sodium acetate, $\mathrm{pH} 6.5,400 \mu \mathrm{M}$ t-o-NAC thioester, $200 \mu \mathrm{M}$ NADPH, and $150 \mathrm{nM} S$. aureus FabI. The rate of decrease in the amount of NADPH in each reaction well was measured using a microtiter ELISA reader using SOFTmax PRO software (Molecular Devices, CA, USA). The inhibitory activity was calculated via the following formula: $\%$ of inhibition $=$ $100 \times[1-($ rate in the presence of compound/ rate in the untreated control)]. The $\mathrm{IC}_{50}$ values were calculated by fitting the data to a sigmoid equation. An equal volume of dimethyl sulfoxide solvent was used for the untreated controls. FabK assays contained $100 \mathrm{mM}$ sodium acetate, $\mathrm{pH} 6.5,2 \%$ glycerol, $200 \mathrm{mM} \mathrm{NH}_{4} \mathrm{Cl}, 50 \mu \mathrm{M}$ t-o-NAC thioester, $200 \mu \mathrm{M} \mathrm{NADH}$, and $150 \mathrm{nM}$ S. pneumoniae FabK. InhA assays contained $30 \mathrm{mM}$ PIPES buffer, $\mathrm{pH}$ 8.0, $100 \mu \mathrm{M}$ t-o-NAC thioester, $100 \mu \mathrm{M}$ NADPH, and $500 \mathrm{nM}$ M. tuberculosis InhA.

Whole-cell antimicrobial activity on $S$. aureus, methicillinresistant $S$. aureus (MRSA), Streptococcus pneumoniae, and Pseudomonas aeruginosa was determined via broth microdilution, as previously described [13]. The test strains were grown to mid-log phase in Mueller-Hinton broth and diluted 1,000-fold in the same medium. Cells $\left(10^{5} / \mathrm{mL}\right)$ were inoculated into Mueller-Hinton broth, except that $S$. pneumoniae was inoculated into tryptic soy broth containing 5\% sheep blood, and then dispensed at $0.2 \mathrm{ml} /$ well in 96-well microtiter plates. MICs were determined in triplicate via the serial dilution of test compounds. The MIC was defined as the concentration of a test compound required to completely inhibit cell growth at $30^{\circ} \mathrm{C}$. Bacterial growth was determined by measuring the absorption at $650 \mathrm{~nm}$ with a microtiter ELISA reader. The minimal inhibitory concentration against Mycobacterium tuberculosis (Mtb) H37Rv was determined by the green fluorescent protein (GFP) reporter microplate assay [3]. Mtb H37Rv-GFP was grown in $10 \mathrm{ml}$ of Middlebrook 7H9 broth (Difco, Sparks, MD, USA) supplemented with $50 \mathrm{mg} / \mathrm{l}$ kanamycin, 0.2\% (v/v) glycerol (Sigma Chemical Co., Saint Louis, MO, USA), $1.0 \mathrm{~g}$ of Casitone (Difco) per liter, $10 \%$ (v/v) OADC (oleic acid, albumin, dextrose, catalase; Difco), and $0.05 \%$ (v/v) Tween 80 (Sigma) until its optical density at $600 \mathrm{~nm}$ reached 0.4 . Test compound solution was added to $7 \mathrm{H} 9$ media, and 2-fold serial dilutions were made in $7 \mathrm{H} 9$ broth in the microplates. The culture was diluted 1:50 in 7H9, and was inoculated to yield $2 \times$ $10^{5} \mathrm{CFU} / \mathrm{ml}$ in plate wells. The plates containing compounds dilutions and Mtb were incubated at $37^{\circ} \mathrm{C}$ for 7 days, and then fluorescence was measured in a Fluostar Optima microplate fluorometer (BMG Labtech, Ortenberg, Germany) in the bottom-reading mode with excitation at $485 \mathrm{~nm}$ and emission at $520 \mathrm{~nm}$. The MRC was defined as the lowest concentration of extracts that inhibited fluorescence by $50 \%$ comparing with the fluorescence of bacteria-only wells.

The effect of FabI inhibitors on the incorporation of $\left[1-{ }^{14} \mathrm{C}\right]$ acetate and $\mathrm{L}-\left[\mathrm{U}-{ }^{14} \mathrm{C}\right]$ leucine in $S$. aureus was measured as described previously [13]. S. aureus was grown to the mid-log phase in LB medium. Each $1 \mathrm{ml}$ culture was treated with drugs for $10 \mathrm{~min}$. An equal volume of DMSO solvent was added to the untreated control. For $\left[1-{ }^{14} \mathrm{C}\right]$ acetate incorporation, $2 \mu \mathrm{Ci}$ of $\left[1-{ }^{14} \mathrm{C}\right]$ acetate was then added to the cultures and incubated at $37^{\circ} \mathrm{C}$ for $1 \mathrm{~h}$ in a shaker. After being harvested by centrifugation, the cell pellets were washed twice with PBS. The total cellular lipids were then extracted with chloroform-methanol-water. The incorporated radioactivity in the chloroform phase was measured by scintillation counting. For $\mathrm{L}-\left[\mathrm{U}-{ }^{14} \mathrm{C}\right]$ leucine incorporation, $0.6 \mu \mathrm{Ci}$ of $\mathrm{L}-\left[\mathrm{U}-{ }^{14} \mathrm{C}\right]$ leucine was added to the cultures and incubated at $37^{\circ} \mathrm{C}$ for $1 \mathrm{~h}$ in a shaker. The incorporation was terminated by the addition of $10 \%$ (w/v) TCA and cooling on ice for $20 \mathrm{~min}$. The precipitated material was collected

Table 1. Comparison of the inhibitory activity of compounds 1-5 against enoyl-ACP reductases, bacterial viability, and intracelluar fatty acid biosynthesis in $S$. aureus.

\begin{tabular}{|c|c|c|c|c|c|c|c|c|c|}
\hline \multirow{2}{*}{ Compounds } & \multicolumn{3}{|c|}{$\mathrm{IC}_{50}(\mu \mathrm{M})$} & \multicolumn{5}{|c|}{$\mathrm{MIC}(\mu \mathrm{g} / \mathrm{ml})$} & \multirow{2}{*}{$\frac{\mathrm{IC}_{50}(\mu \mathrm{M})}{\left[{ }^{14} \mathrm{C}\right] \text {-acetate }}$} \\
\hline & $\mathrm{saFabI}^{\mathrm{a}}$ & $\mathrm{spFabK}^{\mathrm{b}}$ & $m \operatorname{lnh} A^{c}$ & S.a. ${ }^{d}$ & MRSA $^{\mathrm{e}}$ & S.p. ${ }^{f}$ & P.a. ${ }^{\mathrm{g}}$ & M.t. ${ }^{\mathrm{h}}$ & \\
\hline 1 & 4.3 & 3.9 & 11.8 & 128 & 128 & 256 & 256 & 256 & n.t. ${ }^{i}$ \\
\hline 2 & 5.4 & 5.2 & 8.5 & 128 & 128 & 256 & 256 & 256 & 55.3 \\
\hline 3 & 3.0 & 5.2 & 9.6 & 16 & 16 & 64 & 64 & 128 & n.t. \\
\hline 4 & 4.6 & 5.5 & 9.1 & 16 & 16 & 64 & 64 & 128 & 26.3 \\
\hline 5 & $>100$ & $>100$ & $>100$ & $>256$ & $>256$ & $>256$ & $>256$ & $>256$ & $>500$ \\
\hline Triclosan & 0.66 & $>100$ & $>100$ & 0.01 & 0.01 & $>32$ & $>64$ & 16 & 0.04 \\
\hline
\end{tabular}

${ }^{\mathrm{a}}$ S. aureus FabI; ${ }^{\mathrm{b}}$ S. pneumoniae FabK; ${ }^{\mathrm{c}}$ M. tuberculosis InhA; ${ }^{\mathrm{d}}$ S. aureus RN4220; ${ }^{\mathrm{e}}$ MRSA CCARM $3167 ;{ }^{\mathrm{f}}$ S. pneumoniae KCTC $5412 ;{ }^{\mathrm{g}}$ h MRC, the lowest concentration that prevented more than $50 \%$ of the bacterial growth, against P. aeruginosa KCTC 2004 and M. tuberculosis H37Rv, respectively; ${ }^{\mathrm{i}}$ not tested. 
on Whatman GF/C glass microfiber filters, washed with TCA and ethanol, dried, and counted in a scintillation counter. Total counts incorporated at $1 \mathrm{~h}$ of incubation without inhibitors ranged from $>6,000$ for $\left[{ }^{14} \mathrm{C}\right]$ leucine to $>10,000$ for $\left[{ }^{14} \mathrm{C}\right]$ acetate.

Compounds 1-4 strongly inhibited $S$. aureus FabI in a dose-dependent fashion with $\mathrm{IC}_{50}$ of 3-5 $\mu \mathrm{M}$ (Table 1). They also showed the inhibitory activity on $S$. pneumoniae FabK with a similar potency, but exhibited two-times weaker inhibition on M. tuberculosis InhA. In order to determine whether 1-4 inhibit the bacterial cell growth, their antibacterial activity against $S$. aureus, methicillinresistant $S$. aureus (MRSA), S. pneumoniae, P. aeruginosa, and $M$. tuberculosis were evaluated. Interestingly, $\mathbf{3}$ and $\mathbf{4}$ exhibited higher antibacterial activity against $S$. aureus RN4220 and MRSA CCARM 3167 with a MIC of $16 \mu \mathrm{g} /$ $\mathrm{ml}$ than 1 and 2 with a MIC of $128 \mu \mathrm{g} / \mathrm{ml}$ (Table 1). Similarly, 3 and $\mathbf{4}$ exhibited higher antibacterial activity against S. pneumoniae and M. tuberculosis than $\mathbf{1}$ and $\mathbf{2}$.

In order to determine whether the antibacterial effects of panosialins are attributable to the inhibition of intracellular fatty acid biosynthesis, we attempted to ascertain whether the compounds blocked the incorporation of acetate into membrane fatty acids in vivo. We measured the effect of the compounds on the incorporation of $\left[1-{ }^{14} \mathrm{C}\right]$ acetate into the membrane fatty acids in $S$. aureus. Indeed, 4 inhibited fatty acid synthesis in vivo as compared with the untreated cells (Fig. 2). In addition, 4 showed stronger activity with an $\mathrm{IC}_{50}$ of $26.3 \mu \mathrm{M}$ than 2 with an $\mathrm{IC}_{50}$ of $55.3 \mu \mathrm{M}$ (Table 1). The higher inhibitory activity of $\mathbf{4}$ against the intracellular fatty acid biosynthesis than $\mathbf{2}$ is consistent with its higher antibacterial activity, suggesting that the antibacterial

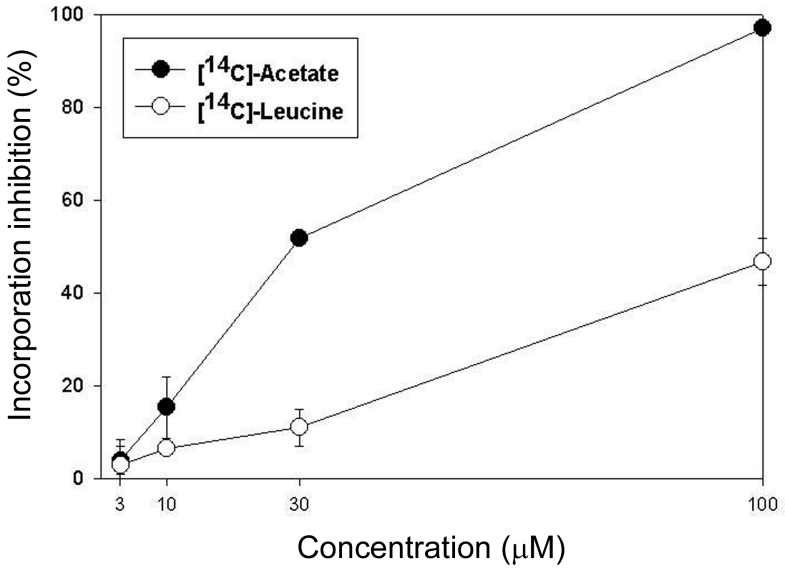

Fig. 2. Effects of panosialin wB (4) on fatty acid biosynthesis and protein biosynthesis in $S$. aureus.

The values were represented as the mean $\pm \mathrm{SD}$ in duplicates obtained from two independent experiments.

activity of panosialins could be due to the inhibition of fatty acid synthesis. Triclosan, used as a positive control, inhibited acetate incorporation. In contrast, the incorporation of leucine into proteins was not influenced by 4 at $30 \mu \mathrm{M}$. Even though 4 started to inhibit protein biosynthesis at $100 \mu \mathrm{M}$, the compound clearly evidenced selective inhibition for fatty acid synthesis. On the other hand, urushil (5), the desulfated derivative of $\mathbf{4}$, did not show any inhibition against enoyl-ACP reductases, fatty acid synthesis, and bacterial growth. It suggested that the sulfate moiety in the panosialins could be involved in the activity. In the Lineweaver-Burk plot analysis (Fig. 3), 4 evidenced a
A

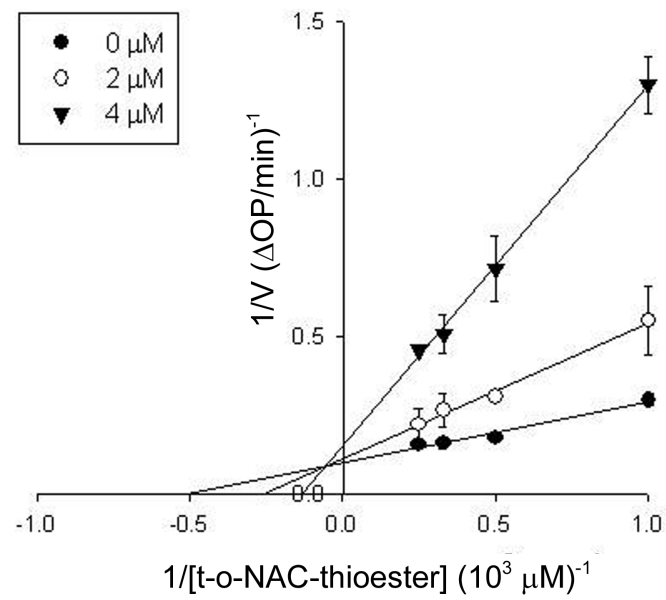

B

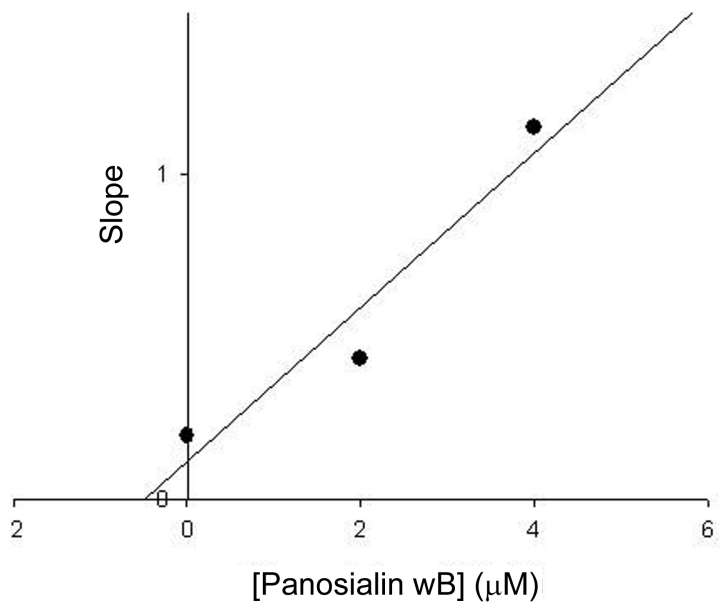

Fig. 3. The mechanism of inhibition of $S$. aureus FabI by panosialin $w B(4)$ respective to t-o-NAC thioester $(\mathbf{A})$ and $\mathrm{K}_{\mathrm{i}}$ determination of panosialin wB (B).

(A) The reciprocals of the initial reaction and substrate concentrations are plotted. (B) The slope values of the lines from graph A are plotted versus the inhibitor concentrations affording a line obtained by linear regression. The intercept point of this line with the $\mathrm{x}$-axis gives an approximate $\mathrm{K}_{\mathrm{i}}$ value of $0.49 \mu \mathrm{M}$ for panosialin $\mathrm{wB}$. The values were represented as the mean $\pm \mathrm{SD}$ in triplicates obtained from two independent experiments. 
mixed-type inhibition against $S$. aureus FabI with respect to the substrate, $\mathrm{t}$-o-NAC-thioester, with a $\mathrm{K}_{\mathrm{i}}$ value of $0.49 \mu \mathrm{M}$. Interestingly, 3 and $\mathbf{4}$ showed the similar inhibitory activity on the enoyl-ACP reductases, but had higher inhibition on fatty acid synthesis as well as bacterial growth than $\mathbf{1}$ and 2, which might be attributed to the higher membrane permeability of $\mathbf{3}$ and $\mathbf{4}$, monosulfated, than $\mathbf{1}$ and $\mathbf{2}$, disulfated.

Panosialins A-C have been reported as the inhibitors of viral sialidase, acid phosphatase, and polygalacturonase [1]. Yamada et al. [10] have re-isolated panosialins A-D and $\mathrm{wA}-\mathrm{wD}$ as inhibitors of glycosidases including $\alpha$ mannosidase, $\alpha$-glucosidase, and $\beta$-glucosidase, from Streptomyces sp. OH-5186. Panosialins wA-wD were reported to show mitogenic activity in spleen cells. Inhibitory activity of panosialins on FabI and fatty acid synthesis was reported for the first time in this study. Since an inhibitor targeting multiple enoyl-ACP reductases is expected to exhibit a broader spectrum of activity, panosialins that inhibit both FabI and FabK, and especially InhA, may have potential for the development of a new broad-spectrum antibacterial.

\section{Acknowledgments}

This work was supported by grants from the NextGeneration BioGreen 21 Program (No. PJ008022), Rural Development Administration, and Basic Science Research Program through the National Research Foundation of Korea (NRF) funded by the Ministry of Education, Science and Technology (2012R1A2A2A01014821).

\section{REFERENCES}

1. Aoyagi, T., M. Yagisawa, M. Kumagai, M. Hamada, Y. Okami, T. Takeuchi, and H. Umezawa. 1971. An enzyme inhibitor, panosialin, produced by Streptomyces. I. Biological activity, isolation and characterization of panosialin. J. Antibiot. 24: 860-869.

2. Campbell, J. W. and J. E. Cronan. 2001. Bacterial fatty acid biosynthesis: Targets for antibacterial drug discovery. Annu. Rev. Microbiol. 55: 305-332.

3. Collins, L. A., M. N. Torrero, and S. G. Franzblau. 1998. Green fluorescent protein reporter microplate assay for highthroughput screening of compounds against Mycobacterium tuberculosis. Antimicrob Agents Chemother. 42: 344-347.

4. Heath, R. J. and C. O. Rock. 2004. Fatty acid biosynthesis as a target for novel antibacterials. Curr. Opin. Investig. Drugs 5: 146-153

5. Kumagai, M., Y. Suhara, T. Aoyagi, and H. Umezawa. 1971. An enzyme inhibitor, panosialin, produced by Streptomyces. II. Chemistry of panosialin, 5-alkylbenzene-1,3-disulfates. J. Antibiot. 24: 870-875.

6. Kwon, Y. J., Y. Fang, G. H. Xu, and W. G. Kim. 2009. Aquastatin A, a new inhibitor of enoyl-acyl carrier protein reductase from Sporothrix sp. FN611. Biol. Pharm. Bull. 32: 2061-2064.

7. McMurry, L. M., M. Oethinger, and S. B. Levy. 1998. Triclosan targets lipid synthesis. Nature 394: 531-532.

8. Moir, D. T. 2005. Identification of inhibitors of bacterial enoylacyl carrier protein reductase. Curr. Drug Targets Infect. Disord. 5: 297-305.

9. Rozwarski, D. A., G. A. Grant, D. H. R. Barton, W. R. Jacobs Jr., and J. C. Sacchettini. 1998. Modification of the NADH of the isoniazid target (InhA) from Mycobacterium tuberculosis. Science 279: 98-102.

10. Yamada, H., K. Shiomi, Q. Xu, T. Nagai, M. Shibata, I. Oya, et al. 1995. New glycosidases inhibitors, panosialins D and wD produced by Streptomyces sp. OH-5186. J. Antibiot. 48: 205210.

11. Zhang, Y. M., S. W. White, and C. O. Rock. 2006. Inhibiting bacterial fatty acid synthesis. J. Biol. Chem. 281: 17541-17544.

12. Zheng, C. J., M. J. Sohn, S.-W. Chi, and W. G. Kim. 2010. Methyl-branched fatty acids, inhibitors of enoyl-ACP reductase with antibacterial activity from Streptomyces sp. A251. J. Microbiol. Biotechnol. 20: 875-880.

13. Zheng, C. J., M. J. Sohn, and W. G. Kim. 2009. Vinaxanthone, a new FabI inhibitor from Penicillium sp. J. Antimicrob. Chemother. 63: 949-953. 